\title{
Head Lice Prevalence and Associated Factors in Two Boarding Schools
} in Sivas

Sivas’ta İki Yatılı Okulda Baş Biti Yaygınlığı ve Etkileyen Faktörlerin Belirlenmesi

\author{
Serpil Değerli', Erdoğan Malatyalı1, Kosta Y. Mumcuoğlu² \\ 'Department of Parasitology, Faculty of Medicine, Cumhuriyet University, Sivas, Turkey \\ 2Department of Microbiology and Molecular Genetics, The Kuvin Centre for the Study of Infectious and Tropical Diseases, Jerusalem, Israel
}

\begin{abstract}
Objective: The aim of the study was to determine the prevalence of head louse infestations and the factors affecting the rate of infestation in primary school children in Sivas.

Methods: A total of 342 children (249 girls and 93 boys) were examined with a louse comb for the presence of head lice. A questionnaire with 23 questions was distributed among the pupils and their parents.

Results: The overall infestation rate for head lice was $10.2 \%(n=35)$. The infestation rate was higher in girls $(13.7 \%)$ than in boys $(1.1 \%)$ $(p<0.05)$. Children who had been infested in the past $(27.1 \%)$ were more likely to be infested than those who had not been infested previously $(7.2 \%)(p<0.05)$. The same was true for children whose family members were previously infested and those who were not $(30 \%$ and $8.5 \%$, respectively) $(p<0.05)$. Head lice infestation was highest $(20 \%)$ in children aged $6-11$ and lowest $(5.3 \%)$ in children aged $13-15(p<0.05)$. The frequency of bathing and washing their hair, sharing combs, beds and towels, the hair color, hair thickness and quantity of dandruff, the number of family members and number of rooms per family member, were not significantly different between infested and non-infested children, A significant difference was found in the infestation of long haired (15.1\%) compared with short haired pupils $(4.5 \%)(p<0.05)$.

Conclusion: Girls were more often infested than boys and children who were previously infested with lice, or came from families where there had been previous infestation, had a greater chance of being re-infested. (Turkiye Parazitol Derg 2013; 37: 32-5)
\end{abstract}

Key Words: Pediculus humanus capitis, head louse, epidemiology, Sivas, Turkey

Received: 10.07.2012 Accepted: 30.11 .2012

\section{ÖZET}

Amaç: Bu çalışmada ilköğretim çağındaki çocuklarda baş biti görülmesini etkileyen faktörlerin belirlenmesi amaçlanmıştır.

Yöntemler: Bu amaçla yatılı ilköğretim bölge okullarında (Merkez YiBO ve Pamukpınar YiBO) öğrenim gören, yaşları 6-15 arasında değişen 249'u kız ve 93'ü erkek olmak üzere toplam 342 çocuk baş biti açısından değerlendirilmiştir. 23 sorulu bir anket çocuklara dağıtılmıştır.

Bulgular: Öğrencilerin 35'inde (\%10.2) bit infestasyonu tespit edilmiştir. Kız öğrenciler arasında (\%13.7) baş biti görülme oranının erkeklere (\%1.1) göre daha fazla olduğu ve aradaki farkın istatistiksel olarak anlamlı olduğu saptanmıştır $(p<0.05)$. Ankete göre, geçmişte bit infestasyonu geçiren öğrencilerin \%27.1'inde tekrar baş biti saptanırken, daha önce bit infestasyonu geçirmeyen öğrencilerin \%7.2'inde yeni bitlenme olduğu bulunmuştur ( $p<0.05)$. Ailesinde bitlenen başka birinin olduğunu bildiren çocuklarda baş biti yaygınlığı (\%30) olmayanlara göre (\%8.5) daha yüksek bulunmuştur ( $p<0.05$ ). Bit infestasyonu 6-11 yaşındaki öğrencilerde (\%20) diğerlerine oranla daha yüksektir $(p<0.05)$. Uzun saçlı öğrencilerin \%15.1'inde ve kısa saçlı öğrencilerin ise \%4.5'inde bit tespit edilmiştir ( $p<0.05)$.

Sonuç: Kızlar, erkeklere nazaran daha fazla infeste olmakta, daha önce bitlenen ve diğer aile üyelerinde bitlenme durumu olan çocukların, tekrar bitlerle infeste olma şanslarının daha yüksek olduğu görülmüştür. (Turkiye Parazitol Derg 2013; 37: 32-5)

Anahtar Sözcükler: Pediculus humanus capitis, baş biti, epidemiyoloji, Sivas, Turkey

Geliş Tarihi: 10.07.2012

Kabul Tarihi: 30.11 .2012

Address for Correspondence / Yazışma Adresi: Dr. Serpil Değerli, Department of Parasitology, Faculty of Medicine, Cumhuriyet University, Sivas, Turkey Phone: +90 3462191010 E-mail: sdegerli@cumhuriyet.edu.tr doi:10.5152/tpd.2013.08 


\section{INTRODUCTION}

Head lice are an ongoing public health problem for children and their parents worldwide. The prevalence of the parasite can greatly vary from country to country and between regions of the same country, and it is usually higher among children aged 3 to 14 years (1-4). The socio-economic level of the examined population, the season in which they were examined, and the hygienic conditions under which children and their families lived, could be of importance (5). Head lice spread rapidly in overcrowded places such as nurseries, schools, prisons, and mental hospitals (4). The gold standard in the diagnosis of head lice is the detection of living adults, nymphs and/or eggs on the scalp. Although most of the studies are conducted by visual inspection of the hair, using a louse comb is approximately 5 times more effective in detecting lice than examination by hand $(6,7)$. Detection of living lice indicates an active infestation, while the presence of nits only indicates a past infestation (8).

The aim of the present study was to determine head lice prevalence in two boarding schools in Sivas, Turkey and to assess the risk factors related to infestation.

\section{METHODS}

\section{Locality of the Schools and Period of Examination}

The present study was conducted during the period of February to May 2011 in a boarding school in the center of the city of Sivas and in Yıldizeli, one of the 17 districts of Sivas. Sivas is located in the eastern part of the central Anatolian region of Turkey and is the capital of the second largest province of Turkey.

At the beginning of the study, teachers and pupils were informed about head louse biology and control by a short power point presentation. Before the physical examination, the hair color (brown, black, blond), hair structure (straight, wavy, curly), hair length (short, medium, long), hair thickness (thin, thick) and presence and quantity of dandruff was noted for each child. A total of 249 girls and 93 boys were examined for the presence of head louse adults, nymphs and eggs/nits. The hair of each child examined for at least 2-3 minutes with the help of a louse comb (Sirma ${ }^{\circledR}$, İstanbul). After examination, the comb was given as a present to the examined child. Collected lice and hair with nits/ eggs, which were cut from the infested child's hair, were preserved in $70 \%$ ethyl alcohol and later brought to the laboratory for more detailed examination under a light microscope.

\section{Questionnaire}

After the examinations, pupils were asked to complete a questionnaire with 23 closed-ended questions. Both parents and teachers were requested to help pupils to fill in the questionnaire and to return it to the examiners. The survey included questions related to the age of the child, the frequency of bathing and washing hair, number of family members, number of rooms per family member at home, and customs of sharing combs, bed and towels.

\section{Statistics Analyses}

The collected data were evaluated using the SPSS for Windows 14 program. Results were considered to be of statistical significance if the relevant $p$-value was $<0.05$.

\section{RESULTS}

The overall prevalence of head louse infestation in the two boarding schools was $10.2 \%$. No statistical difference was observed between the two schools regarding louse infestation. Out of 35 infested children, 16 were infested with nits alone, 11 with all stages of the parasite, 5 with nymphs and 3 with adult lice only. Girls were significantly more infested (13.7\%) than boys $(1.1 \%)(p<0.05)$. Schoolchildren who had been infested in the past with lice were more infested $(27.1 \%)$ than those who had not been infested before (7.2\%) $(p<0.05)$. The same was true for children whose family members were previously infested with lice than those coming from families who had never had lice (30\% and $8.5 \%$, respectively) $(p<0.05)$ (Table 1$)$. Head louse infestations were highest (20\%) in children aged 6-11 and lowest in children aged 14-15 ( $p<0.05)$ (Table 2). The frequency of bathing and washing hair, number of family members, number of rooms per family member, habits of sharing combs, bed and towels, hair color, hair thickness and quantity of dandruff, were not significantly different between infested and non-infested children. A significant difference was found between longhaired (15.1\%) and shorthaired pupils $(4.5 \%)(p<0.05)($ Table 3,4$)$. In the majority of cases $(81.1 \%)$, the mothers were responsible for the diagnosis and treatment of head lice.

\section{DISCUSSION}

A total of 342 schoolchildren were screened for the presence of head lice and, in 35 of them (10.2\%), head lice were detected. In

Table 1. Prevalence of head lice infestation in relation to infestation in the past, infestation of another family member and level of knowledge in pupils regarding head lice

\begin{tabular}{|l|c|c|}
\hline & $\begin{array}{c}\text { Actually } \\
\text { infested } \\
\mathbf{n}(\%)\end{array}$ & $\begin{array}{c}\text { Statistical } \\
\text { analysis }\end{array}$ \\
\hline $\begin{array}{l}\text { Infestation with lice in the past } \\
\text { Yes }\end{array}$ & $\begin{array}{c}13(27.7) \\
\text { No }\end{array}$ & $\begin{array}{c}\chi^{2}=18.89 \\
p<0.05\end{array}$ \\
\hline $\begin{array}{l}\text { Infestation with lice of other } \\
\text { family members } \\
\text { Yes }\end{array}$ & $9(30)$ & $\chi^{2}=13.61$ \\
No & $26(8.5)$ & $p<0.05$ \\
\hline $\begin{array}{l}\text { Knowledge of head lice } \\
\text { Yes }\end{array}$ & $14(9.7)$ & $\chi^{2}=0.26$ \\
No & $20(10.3)$ & $p>0.05$ \\
\hline
\end{tabular}

Table 2. Prevalence of head lice by age in two primary boarding schools

\begin{tabular}{|c|c|c|c|}
\hline $\begin{array}{l}\text { Age of the } \\
\text { examined } \\
\text { child }\end{array}$ & $\begin{array}{l}\text { Number } \\
\text { examined }\end{array}$ & $\begin{array}{l}\text { Positive for } \\
\text { head lice } \\
\text { n (\%) }\end{array}$ & $\begin{array}{c}\text { Statistical } \\
\text { analysis }\end{array}$ \\
\hline $6-9$ & 30 & $6(20.0)$ & \multirow{4}{*}{$\begin{array}{l}\chi^{2}=6.59 \\
p<0.05\end{array}$} \\
\hline $10-12$ & 198 & $23(11.6)$ & \\
\hline $13-15$ & 114 & $6(5.3)$ & \\
\hline Total/Average & 342 & $35(10.2)$ & \\
\hline
\end{tabular}


Table 3. Prevalence of head lice infestation in relation to hair color, hair structure, hair length, hair thickness and quantity of dandruff

\begin{tabular}{|c|c|c|c|}
\hline & $\begin{array}{l}\text { Number } \\
\text { examined }\end{array}$ & $\begin{array}{l}\text { Positive for } \\
\text { head lice } \\
\text { n (\%) }\end{array}$ & $\begin{array}{l}\text { Statistical } \\
\text { analysis }\end{array}$ \\
\hline \multicolumn{4}{|l|}{ Hair color } \\
\hline Brown & 156 & $21(13.5)$ & \multirow{3}{*}{$\begin{array}{l}\chi^{2}=4.32 \\
p>0.05\end{array}$} \\
\hline Black & 143 & $9(6.3)$ & \\
\hline Yellow & 42 & 5 (11.9) & \\
\hline \multicolumn{4}{|l|}{ Hair style } \\
\hline Straight & 229 & $21(9.2)$ & \multirow{3}{*}{$\begin{array}{l}\chi^{2}=2.10 \\
p>0.05\end{array}$} \\
\hline Curly & 27 & $2(7.4)$ & \\
\hline Wavy & 83 & $12(14.5)$ & \\
\hline \multicolumn{4}{|l|}{ Hair length } \\
\hline Short & 132 & $6(4.5)$ & \multirow{3}{*}{$\begin{array}{l}\chi^{2}=7.89 \\
p<0.05\end{array}$} \\
\hline Medium & 123 & $16(13)$ & \\
\hline Long & 86 & $13(15.1)$ & \\
\hline \multicolumn{4}{|c|}{ Hair thickness } \\
\hline Thin & 230 & $22(9.6)$ & \multirow{2}{*}{$\begin{array}{l}\chi^{2}=0.48 \\
p>0.05\end{array}$} \\
\hline Thick & 108 & $13(12)$ & \\
\hline \multicolumn{4}{|c|}{ Dandruff problem } \\
\hline Yes & 125 & $13(10.4)$ & \multirow{2}{*}{$\begin{array}{l}\chi^{2}=0.0 \\
p>0.05\end{array}$} \\
\hline No & 216 & $22(10.2)$ & \\
\hline
\end{tabular}

Table 4. Prevalence of head lice infestation in relation to frequency of bathing, washing hair, and sharing personal items

\begin{tabular}{|c|c|c|c|}
\hline & $\begin{array}{c}\text { Number } \\
\text { examined }\end{array}$ & $\begin{array}{l}\text { Positive for } \\
\text { head lice (\%) }\end{array}$ & $\begin{array}{c}\text { Statistical } \\
\text { analysis }\end{array}$ \\
\hline \multicolumn{4}{|l|}{ Bathing frequency } \\
\hline Once a week & 73 & $7(9.6)$ & \multirow{3}{*}{$\begin{array}{l}\chi^{2}=0.62 \\
p>0.05\end{array}$} \\
\hline Twice a week & 173 & $20(11.6)$ & \\
\hline Three times a week & 93 & $8(8.6)$ & \\
\hline \multicolumn{4}{|l|}{ Hair washing frequency } \\
\hline Once a week & 70 & $8(11.4)$ & \multirow{3}{*}{$\begin{array}{l}\chi^{2}=1.34 \\
p>0.05\end{array}$} \\
\hline Twice a week & 143 & $17(11.9)$ & \\
\hline Three times a week & 128 & $10(7.8)$ & \\
\hline \multicolumn{4}{|c|}{ Sharing combs, bed and/or towels } \\
\hline Yes & 154 & $13(8.4)$ & $\chi^{2}=0.62$ \\
\hline No & 153 & $17(11.1)$ & $p>0.05$ \\
\hline
\end{tabular}

Turkey, several studies of head louse epidemiology were conducted and a wide range of infestation rates (0.7-59\%) was observed (9). Some of the important reasons for the different outcomes obtained in these studies were the region's socioeconomic position, age group studied, study period (year, month), children's gender, different examination modalities (visual inspection vs. examination with a louse comb) and whether nits were considered as a sign of infestation. In pupils coming from families with higher socio-economic status in Konya, the infesta- tion rate was $0.6 \%$, while in children from the provinces of this city with lower socio-economic levels, the infestation rates were 2.1$13.2 \%$ (10). Prevalence studies conducted in school children from Malatya in 2004 and 2007 demonstrated infestation rates of 1.1\% and $5.1 \%$, respectively $(4,11)$. Üner et al. (12) examined 2,906 children in Izmir and reported an infestation rate of $1.5 \%$. Güleç et al., (13) who examined children from a low socio-economic level in the Ankara region, found an infestation rate of $5.2 \%$. In Kayseri, $9.2 \%$ of 1,261 primary school children were positive for head lice, while in Sakarya, a prevalence of $34.1 \%$ was reported $(3,14)$. In epidemiological studies conducted in Sivas in the years $1990,1993,2002,2006$ and 2010 infestation rates of $7.3 \%, 3.6 \%$, $1.1 \%, 9.5 \%$ and $5.9 \%$, respectively, were found (15-19).

In the present study, girls were significantly more infested than boys. Payzin reported an infestation rate of $54 \%$ in girls and $17.2 \%$ in boys (14). Daldal et al. (11) found lice in $2 \%$ of the girls and in none of the boys examined. Artan et al. (3) reported a prevalence of $2.1 \%$ in boys and $16.4 \%$ in girls. This phenomenon could be explained by the fact that girls have longer hair, which facilitates the transmission of lice from head to head, and they are more sociable, frequently touching other girls' hair. In addition, in long hair, nits remain attached as the hair grows and accordingly, these signs of previous infestations, which had been treated successfully, remain for months, while a short hair-cut in boys, removes the nits.

In this study, no significant differences were found between different hair colour hair structure and hair density. Borges et al. (20) reported that girls with long, dark and wavy hair were more infested, while they found no differences between the different hair colors and structures.

In the present study, children 6-10 years-old were more frequently infested than other age groups. This is in agreement with Ozcelik et al. (18) who found that first grade students (6-7 years old) were more infested than other age groups. Kamiabi et al. (21) also reported that 9-year-old children were the most infested age group.

Çiftçi et al. (22) stressed the importance of socio-economic status and parental education related to head louse infestation, emphasizing that children from lower socio-economic levels and those who had parents with lower education were more frequently infested. Heukelbach et al. (23) also reported that children under the age of 15 , who lived in rural areas, were more often infested.

\section{CONCLUSION}

Girls were more often infested with head lice than boys were, and children who were previously infested with lice, as well as children from families where there had been previous infestations, had a greater chance of being re-infested.

\section{Acknowledgement}

We would like to thank Dr. Jacqueline Miller and Dr. Avi Keysary for their critical review of the manuscript.

\section{Conflict of Interest}

No conflict of interest was declared by the authors. 


\section{REFERENCES}

1. Budak S, Delibaş SB. Pediculosis ve phthiriosis. In: Özcel MA (Ed): Özcel'in Tıbbi Parazit Hastalıkları. 1st ed, 845-847. Türkiye Parazitoloji Derneği Yayınları, İzmir, 2007.

2. Akisu C, Aksoy U, Delibas SB, Ozkoc S, Sahin S. The prevalence of head lice infestation in school children in izmir, Turkey. Pediatr Dermatol 2005; 22: 372-3. [CrossRef]

3. Artan MO, Baykan Z, Koc AN. Kayseri ili kırsalındaki sekiz ilköğretim okulunda Pediculus capitis prevalansı. Türkiye Parazitol Derg 2006; 30: 112-24.

4. Atambay M, Karaman O, Karaman U, Aycan O, Yoloğlu S, Daldal N. [The frequency of intestinal parasites and head lice among students of the Akşemsettin Primary School for Deaf Students]. Turkiye Parazitol Derg 2007; 31: 62-5.

5. Dursun N, Cengiz ZT. Van'ın Erciş ilçesinde baş bitinin yayılışı. Türkiye Parazitol Derg 2010; 34: 45-9.

6. Mumcuoglu KY, Friger M, loffe-Uspensky I, Ben-Ishai F, Miller J. Louse comb versus direct visual examination for the diagnosis of head louse infestations. Pediatr Dermatol 2001; 18: 9-12. [CrossRef]

7. Balcioglu C, Burgess IF, Limoncu ME, Sahin MT, Ozbel Y, Bilaç C, et al. Plastic detection comb better than visual screening for diagnosis of head louse infestation. Epidemiol Infect 2008; 136: 1425-31. [CrossRef]

8. Mumcuoglu KY, Barker SC, Burgess IE, Combescot-Lang C, Dalgleish $\mathrm{RC}$, Larsen KS, et al. International guidelines for effective control of head louse infestations. J Drugs Dermatol 2007; 6: 409-14.

9. Falagas ME, Matthaiou DK, Rafailidis PI, Panos G, Pappas G. Worldwide prevalence of head lice. Emerg Infect Dis 2008; 14: 1493-4. [CrossRef]

10. Oflaz M. Konya'da sosyo-ekonomik yönden farklı olan iki bölgedeki ilköğretim okullarındaki çocuklarda Pediculus humanus capitis yaygınlığı Selçuk Üniv., Sağlık Bil. Enst. Parazitoloji (Vet) Anabilim Dalı Yüksek Lisans Tezi, 2006.

11. Daldal N, Atambay M, Aycan ÖM, Karaman Ü, Ersoy Y. Malatya'da iki ilköğretim okulu çocuklarında Pediculus capitis yaygınlığının araştırılması. İnönü Üniv Tıp Fak Derg 2000; 11: 11-3.
12. Üner A, Özensoy S, Tappeh KH, Akar Ş, Gürüz Y, Kundakçı Ü. İzmir Karşıyaka ilçesi ilkokul çocuklarında bağırsak parazitleri ve baş biti araştırılması. Türkiye Parazitol Derg 1997; 21: 39-43.

13. Güleç M, Kır T, Tekbaş ÖF, Ceylan S, Hasde M. Çiçekli İlköğretim Okulu öğrencilerinde Pediculus humanus capitis enfestasyonu prevalansının ve buna etki eden faktörlerin araştıııması. Türk Hij Den Biyol Derg 2000;57: 13-18.

14. Payzın F. Sakarya söğütlü sağlık ocağı bölgesindeki ilkokul birinci sınıflarda baş biti prevalansı. Türkiye Klinikleri J Med Sci 1995; 15: 57-60.

15. Saygı G, Özçelik S, Temizkan N, Erandaç M. Sivas'ta üç ilkokul ögrencileri arasında Pediculus humanus capitis yaygınlığının araştırılması. Türkiye Parazitol Derg 1990; 14: 75-83.

16. Öztürkcan S, Özçelik S, Saygı G. Sivas çocuk yuvasındaki çocuklar arasında Scabies ve Pediculus humanus sıklığının araştırılması. Türkiye Parazitol Derg 1993; 17: 42-6.

17. Saygı G, Oğuztürk H, Akın Z. İki köy ilköğretim okulu öğrencilerinde Pediculus türlerinin araştıııması. Türkiye Parazitol Derg 2002; 26: 192-4.

18. Özçelik S, Değerli S, Aslan A. Sivas Alahacı köyü ilköğretim okulu öğrencilerinde Pediculus yaygınlığının araştırılması. Türkiye Parazitol Derg 2006; 30: 184-6.

19. Değerli S, Malatyali E, Çeliksöz A, Özçelik S, Mumcuoğlu KY. The prevalence of Pediculus humanus capitis and the coexistence of intestinal parasites in young children in boarding schools in Sivas, Turkey. Pediatr Dermatol 2012; 29: 426-9. [CrossRef]

20. Borges R, Mendes J. Epidemiological aspects of head lice in children attending day care centres, urban and rural schools in Uberlandia, central Brazil. Mem Inst Oswaldo Cruz 2002; 97: 189-92. [CrossRef]

21. Kamiabi F, Hosain FN. Prevalence of pediculosis capitis and determination of risk factors in primary-school children in Kerman. East Mediterr Health J 2005; 11: 989-92.

22. Ciftci IH, Karaca S, Dogru O, Cetinkaya Z, Kulac M. Prevalence of pediculosis and scabies in preschool nursery children of Afyon, Turkey. Korean J Parasitol 2006; 44: 95-8. [CrossRef]

23. Heukelbach J, Wilcke T, Winter B, Feldmeier H. Epidemiology and morbidity of scabies and pediculosis capitis in resource-poor communities in Brazil. Br J Dermatol 2005; 153: 150-6. [CrossRef] 